\title{
Social Communication of Farmers in Establishing Food Security Recovery
}

\author{
Rully Khairul Anwar \\ (FIKOM University of Padjadjaran; rully.khairul@unpad.ac.id) \\ Edwin Rizal \\ (FIKOM University of Padjadjaran; edwin.rizal@unpad.ac.id) \\ Elnovani Lusiana \\ (FIKOM University of Padjadjaran; elnovani.lusiana@unpad.ac.id)
}

\begin{abstract}
This study aims at gaining an overview of farmers' community in rural areas about a social communication model among them who have cultivated farmland from generation to generation. The qualitative and descriptive study in a village in Garut, West Java, found that there were patterns of traditional communication maintained by the majority of farmers as well as open communication patterns with absorbs the modernization of development. With social communication pattern, it is clear that there are efforts to strengthen the food resilience of rural communities which are sufficiently dynamic to reduce the imbalance between rural and urban areas, reduce the level of dependence of the city, increase the income of farmers, and empowerment of farmers and poor communities in rural areas.
\end{abstract}

\section{Keywords: Social Communication, Rural Development, Farmer's Empowerment}

\begin{abstract}
Abstrak
Kajian ini bertujuan untuk mendapatkan gambaran umum komunitas petani di daerah pedesaan tentang model komunikasi sosial di antara mereka yang telab mengolah lahan pertanian dari generasi ke generasi. Studi kualitatif dan deskriptif di sebuah desa di Garut, Jawa Barat, menemukan bahwa ada pola komunikasi tradisional yang dipelihara oleh sebagian besar petani serta pola komunikasi terbuka dengan menyerap modernisasi pembangunan. Dengan pola komunikasi sosial, jelas bahwa ada upaya untuk memperkuat ketahanan pangan masyarakat pedesaan yang cukup dinamis untuk. mengurangi ketidakseimbangan antara daerah pedesaan dan perkotaan, mengurangi tingkat ketergantungan pada kota, meningkatkan pendapatan petani, dan pemberdayaan petani dan masyarakat miskin di daerah pedesaan.
\end{abstract}

Kata kunci: Komunikasi Sosial, Pembangunan Pedesaan, Pemberdayaan Petani 


\section{A. INTRODUCTION}

The decade of the sixties has declared the first decade of world development. The decade of the seventies as the second decade of growth; and the decade of the eighties as the third decade of development. The above statement departs from the fact that in the world at the beginning of the twenty-first century, there are many problems, both in one country and in the relationship between nations in such aspects of life as in politics, economics, technology, and security. These problems can only be solved by the implementation of comprehensive development activities, in the sense of covering all aspects of national and state life (Naude, 2013: 1).

According to Szeles (2014: 7), development is a multidimensional process (multidimensional) covering the orientation and organizational changes of the social, economic, political, and cultural systems. Village developments are activities undertaken by the community so that they can identify needs and problems together. While Ascani et al. (2012: 4) state that rural development is a process in which members of the village community first discuss and determine their desires, then plan and work together to fulfill their wishes.

So it can be concluded that the development of village communities as activities that the villagers planned themselves, by identifying together the various problems and potentials that exist in the rural environment that the results can create socio-economic progress of village communities, and participatory of the community itself vital in the development of rural communities. 
Rural development is also multi-dimensional and multi-faceted. Therefore, it is necessary to conduct a more focused analysis or discussion in the context of all aspects of the field or sector and issues outside the rural (physical and nonphysical, economic and non-economic, socio-cultural, spatial and non-spatial). Participation of the community in development (rural) is the actualization of the awareness, the willingness of the community to sacrifice and contribute to the implementation of programs implemented in the region. Prihartono (2012: 226) asserts, "As the purpose of development is to stimulate economic growth aimed at solving population and employment problems. Therefore, rural development must conform to the dominant economic potential. Moreover, rural development is an essential part of the national development that must pay attention to the equitable distribution of development, sustainable economic growth, and national economic stability".

Development policy encourages the creation of quality employment in rural areas by stimulating the economic growth activities of agricultural enterprises in addition to improving rural community empowerment through enhancing the quality of both as actors and as development resources, as well as strengthening institutions and social capital of rural communities.

The development of rural communities more emphasizes on the creation of conditions. That encourages development by utilizing the potential resources available in rural areas to provide benefits from this development for the village government, and especially the general public, by opening business fields in the surrounding villages from various sectors such as from agriculture, the business 
community (home industry) and even manufacturing and thus attracting private investment to invest capital for business actors in the countryside.

Empowerment is part of the development paradigm that focuses its attention on all aspects of the principle of humanity in the environment ranging from intellectual elements (human resources), material and physical points to the managerial perspective. Empowerment has the same meaning as community independence. It is related to the development program. The goal to be achieved is to form an individual and an independent society.

Empowerment comes from the word power (power or empowerment), so the idea of empowerment comes into contact with the concept of power. Indeed, language-based empowerment comes from the word 'power,' which means energy or power, empowerment is the effort to build resources by encouraging, motivating and awakening awareness of potential possessed and working to develop it (Szeles, 2014: 6).

It concludes that initially, the community is an object in development, now it is just the opposite of society as a subject in development. All government projects and programs involve communities using empowerment and community participation in their implementation so that communities are in the position of determining the success of development programs. So community empowerment should follow a focused, participatory, and group approach. What is meant by the effort must be directed is that the energy should be a sense of partiality. This effort is addressed directly to the needy, with programs designed to solve problems and fit their needs (Santos et al., 2016: 2). 
The second is that the development program is participatory. That is, the target communities are the actors for the implementation. There are several objectives, i.e., the aid is useful because it is by the will, ability, and needs of the community. Also, improving the strength of the community with experience in designing, implementing, managing, and accountable for its self-improvement and economic efforts.

The third is that the development program must use a group approach. That is because independently, it is difficult for the poor to solve the problems it faces. Also, the scope of assistance becomes too broad if the handling individual. This group approach is most effective and seen from the use of resources is also more efficient. Community empowerment must involve all the potential that exists in society. Some aspects of which are as follows:

1. The role of government is significant. It means that the government bureaucracy must be able to adapt to this mission,

2. Community organizations outside the community. In this case, the potential of a significant role is non-governmental organizations (NGOs), in addition to community organizations that are national and local.

3. Community institutions that grow from and within the community, or often referred to as local community organizations. These institutions can be semi-formal or quasi-like, such as LKMD, PKK, or Karang Taruna, or who grow from the community, such as a grouping of mothers and the like (Prihartono, 2012: 252-553). 
Through group meetings, various views are expended, and the interests of the population arise in the form of a desire to do something to solve their problems. When the desire grows from their own, then they can be moved for action, because the decision to do something comes from their own. Through discussions and elections and problem solving, leaders appear to direct the officer (village) in using this method, it should first have the results of research to succeed the process, and the method involves the people in the discussion which then in itself formed the formation of groups and group activities. It is commonly called social communication, or it can also be called leadership communication (Supratman, 2017).

In social communication, frequent communication within an organization is extended to different groups. For example, concerning community empowerment, this social communication involves all the components that exist in society such as village governance in this case, government officials can help solve problems that can not be overcome by the community also helps the community guide all activities undertaken by the community. Then the importance of existing community organizations from outside the community environment, such as community or NGO (Non-Governmental Organization), which serves as the implementation of the program by helping people in the empowerment program, can also develop their program. And most importantly, the Village community itself, which as a problemsolver, program planners and program implementers, by developing existing community institutions in the village such as youth, PKK, and others. 
As well as being in Garut regency stands a community that originated from the discussion of the youth who was called his heart to be able to provide benefits in this Garut Regency. From the results of the discussion, then formed a community called Creavill or Creative Village or in the Indonesian language means creative village. Creavill's program is the development of villages by using community empowerment in the field of economy, education, and livestock, especially in the region of Garut Regency.

In 2013 Creavill community created a program called "Beberesih Eceng Gondok" in Situ Bagendit because this water hyacinth covered almost half of Situ Bagendit. One hundred people from college students attended the program to high school and junior high school students to clean the water hyacinth that covered Situ Bagendit. Because of the amount of water hyacinth Creavill Community gives the idea to make this water hyacinth as food and craft that is economical and marketable. So the community began to produce food and handicraft made from water hyacinth. Then in Kampung Kiaralawang Sukamukti Village is building a hall called "Balai Kreatif" (Creative Building) which serves as a place to distribute the products made from water hyacinth, and also as a gathering place for Creavill community with the community, for example, discussing, preparing the next program and even counseling.

Continuing in 2014, Creavill Community also gives ideas to villagers. Creavill to make sheep farming because many Creavill Village communities keep sheep. Then came to the group of sheep breeders, and named as Creative breeders. In 2015 from Kampung Kiaralawang Sukamukti village, there is awarded as the Best Youth Cadre 
in Garut Regency. Here is why there is a reason to write how the social communication that occurs in the development of village-based community empowerment in Garut Regency.

\section{B. LITERATURE REVIEW}

Community development is mainly an effort to empower the community through the ability and potential of the community itself. In this regard, the community is the participant, as well as the developer of development. Community development is sometimes viewed as the opposite of a top-down development approach that is determined from outside the community.

Development is a political, economic, social concept to direct the process of change that sweeps the whole world in the direction desired by a nation through the constitution of representation and government (Santos et al., 2016: 3). Thus, development as a business or business series of growth and change that plan and consciously by a nation, state, and government toward modernity in the framework of nation-building (Naude, 2013: 5). Development is a multi-dimensional process (multidimensional) covering the orientation and organizational changes of the social, economic, political, and cultural systems. Village development is defined as activities undertaken by the community so that they can identify needs and problems together. There is also a definition of community development as a planned activity to create conditions for the socio-economic progress of society by increasing community participation. In other words, community development is a blend of socio-economic development and community organizing (Prihartono, 2012: 219). 
Development is an effort for growth and changes in social and economic wellbeing planned by the community and government by increasing the participation of the community to identify the problems and potentials together, especially the development of village communities, the whole community and government play an active role in programs and the implementation of community development to create social and economic progress (Anwar et.al., 2018).

Meanwhile, David McClelland, a social psychologist, is interested in development issues because of the poverty and backwardness of many people in the world. In his paper, McClelland concludes that to do a successful job, the most important is the attitude towards the job. From there, McClelland arrives at his great concept, the need for Achievement, the need, or the drive for achievement. This concept is abbreviated by a symbol which then becomes very famous, namely $n$-Ach. As in the idea of Protestant Ethics, the desire, need, or drive for achievement is not merely to achieve substantial material rewards. People with high n-Ach, who need achievement experience satisfaction not because of getting rewarded from the results of his work, but because the work is considered very good. There would be inner satisfaction if the work completed correctly. Material rewards become secondary factors. With the concept of n-Ach, we see Max Weber's influence on McClelland (Lewis, 1991: 1266). It can be concluded that David McClelland's development theory puts more emphasis on the psychology of the society in which David McClelland concludes that to make a development program work is the most crucial attitude of the community itself whether society is enthusiastic in implementing the 
development program or not, the determinants of a development program is successful or not.

According to Chistilin (2006: 135), development should apply the following principles:
a. Transparent (openness).
b. Participation.
c. It can be enjoyed by the community.
d. Accountable (accountability)
e. Sustainable (sustainable).

According to Dang and Pheng (2015: 12), the goals of rural community development, in general, can be formulated as follows:

1. The creation of general conditions that promote development.

2. The utilization of potential resources to provide benefits for development by the local government (concerned) business world and the general public.

3. Implementation of all investigations in various sectors.

4. Implementation of the steps in implementing and then the impetus for private activities and investment.

From the above characteristics, it can be said that the development of rural communities is a process by which members of the village community first discuss and plan and work together to fulfill their wishes (Ascani et al., 2012: 6). From the definition, it is clear that the development of the village community is the development effort undertaken by the villagers. They gathered to deliberate their 
everyday needs. Identify these needs, inventory them according to the level or degree of need either concerning the public interest or concerning urgency or lack thereof.

Rural development is an integral part of national development, which is an effort to improve the quality of rural and community human resources as a whole, which is done continuously based on rural potency and capability. In its implementation, rural development should refer to the achievement of development goals, namely to realize the life of rural communities that are independent, advanced, prosperous, and just (Prihartono, 2015: 233).

In some rural areas, the goal of development is to stimulate economic growth aimed at solving population problems such as poverty and employment. Therefore, rural development must conform to the dominant economic potential of the village. Moreover, rural development is an essential part of the national development that must pay attention to the equitable distribution of development, sustainable economic growth, and national economic stability. It can be concluded that the policy of rural development is directed to encourage the creation of quality employment in rural areas by stimulating the economic growth activities of rural enterprises such as agriculture. From there, development is also directed to improve the empowerment of rural communities through improving the quality of both as actors and as development resources, as well as strengthening institutions and social capital of rural communities.

Meanwhile, empowerment is part of a development paradigm that focuses its attention on all aspects of the principle of humanity in its environment ranging from aspects of intellectual (human resources) material and physical aspects to managerial 
aspects. The definition of empowerment presented by experts is very diverse and contextual. However, various definitions say that the empowerment of society is an effort to enable and sustainable community. In other words, it is an effort to help people to help themselves.

\section{METHOD}

This research uses a qualitative approach. It is because this research explores and defines what for some people as a social or humanitarian problem (Cresswell, 2010: 146), resulting in descriptive data of observable words or behaviors (Bogdan and Taylor in Moleong, 2012: 4). While the method used in this research is a descriptive method, which is to represent the symptoms of the problems studied. As a result, this is an observation and natural atmosphere (natural setting) (Rakhmat, 2012: 24). The method is particularly suitable for researching rural development issues, as this is natural, profound, and complex (Der Wagen, 2001: 5).

\section{FINDINGS AND DISCUSSION}

Development is a large and interconnected project among stakeholders in a country. Similarly, development in an area such as rural areas, development must be done by various parties, be it government, employers, and society in general. Therefore the emergence of various groups that support development is highly desirable if the area is to move forward.

In Garut regency, the creation of a Creative Village is a real picture of the existence of development efforts by the community. Empowerment programs 
conducted by the Creative village community include the presence of food and handicraft made from water hyacinth. Food made from water hyacinth may not be very nutritious, but it can increase the fiber absorption into the body, thus bringing the body's resistance to disease while the craft is made in a variety of items needed as additional goods and used in everyday life. Handicraft is a designation for an artwork. The word craft comes from the word 'diligent' which means goods/objects produced by the skill of the hand - handicraft made of various materials. This handicraft produces ornaments or art objects or wears goods. Usually, this term is applied to the traditional way of making goods or clothing that is used every day.

Then the next program that existed in the Creative Village community is a sheep breeding called the village of creative breeders. So that this farm, when seen in its empowerment breeders, can play a significant role in improving the quality of nutrition of the people's food in addition to as a source of income, both for the farmers themselves and for the country as a whole. It is said to be important in improving the nutritional quality of the people's food because the variety of livestock products is one of the primary sources of animal protein that is very necessary for an effort to improve the health of the people. As a source of income is said to be important because, in general, there is not much difficulty in marketing livestock products, both domestically and abroad (Naude, 2013: 13).

In the Creative Village program, there is also an educational program in which volunteers or members of Creative Village provide counseling about crafting that is economically valuable and also by providing books for creative villages. According to Naude (2013: 15) educational programs not only focus on specific levels and levels of 
education such as kindergartens, elementary schools, high schools, vocational and higher education, but also to other groups that need education such as illiteracy restrictions, community education, vocational exercises that seek to provide specific technical skills that all thrive exponentially because of the demands of modern life and development. The importance of the education sector with all its programs in the framework of national development so that there is an opinion that the most critical investment that can be made by a developing country is an investment in human resources. It means that intensive education sector development is significant.

Empowerment is one effort in building social and economic welfare of the community with various elements of society both from the community itself and from the government then also from institutions outside government as well as Creavill encourage the implementation of empowerment program in Kampung Kiaralawang that is with the production of food and creative craft from water hyacinth made by the mothers of Kiaralawang, the existence of Rumba (House of Reading) which is beneficial for children even all the villagers of Kiaralawang in adding science and the existence of sheep's creative livestock managed by the Dhuafa to improve the economy and some of the results also for children orphan. The impact of empowerment in Kiaralawang village are:

1. Community productivity increases.

2. The income of the community increases because there are often orders.

3. With this program, the children are motivated and controlled because there is a program for children, namely one youth, one child, and home reading, which ultimately the enthusiasm of children in education becomes excellent. 
4. The involvement of youth in youth is more productive and creative (Interview with KA, community leader Kiaralawang, August 5, 2017).

The result of this empowerment is indeed seen in the village of Kiaralawang, where the community is more productive, especially in the mothers of Kiaralawang whoa two times a week make food and creative craft from water hyacinth. It can increase the economy of mothers who follow the empowerment program by making a creative craft. Then the water hyacinth handicraft is also economic value because there are often ordered so it can increase the income of mothers in the economy (Interview with IM, craftsmen in Kiaralawang, August 5, 2017).

The craftsmen group can only feel the impact of Creavill's empowerment in this village, but it can not affect the general public. It has not seen a significant impact similarly, because people have their respective professions such as making dodol (sweet food out of rice), making eyelashes, and others (Interview with AT, village officials in Kiaralawang, August 5, 2017). However, the empowerment program through the manufacture of food and water hyacinth crafts is still running today, although the manufacture of food and water hyacinth handicrafts has not been cited as a primary livelihood in Kampung Kiaralawang.

Indeed food and water hyacinth handicrafts cannot be used as a primary livelihood in the community Kiaralawang village. But the efforts of Kiaralawang mothers who are productive in developing these products are following the efforts of empowerment regarding building resources in this case water hyacinth and able to develop water hyacinth into a potential that can be valuable food and economical food and craft water hyacinth. Not forgetting that this can not be separated from the 
motivational motivation and awareness of the community Kiaralawang village will have the potential.

Then education for children also exist, namely in the form of Rumba (home reading) and there is also one youth one-child program, this program is intended for orphans in meeting the needs of the school. This program is seen as the enthusiasm of children in adding knowledge by reading that facilitated by the Rumba (home read). It aims to increase knowledge and form the character of children behave and good personality also diligent in reading books because of children in the village of Kiaralawang still many who read in Rumba Kiwang this.

Similarly, the youth in the village of Kiaralawang who assist in empowerment, resulting in more productive and creative youth in helping to develop the potential that exists in the village of Kiaralawang. It is proven by the selection of one of the younger generation Kiaralawang, namely Tea Fitri, to get an award by the government of Garut as a Youth Kretif 2015 (Interview with KA, community leaders Kiaralawang, August 5, 2017).

The form of appreciation given by Creavill is recommending Fitri as the creative youth of 2015. With Fitri being selected as creative youth from Kiaralawang village, the creative product from water hyacinth can be introduced to all Garut people, proven by always invited in various SME event in Garut and provide a place to promote creative craft food products from the water hyacinth to the broader world (Interview with KA, community leader Kiaralawang, August 5, 2017).

It proves that the people of Kiaralawang village have excellent social communication so they can mobilize and utilize the network. Development by using 
social communication is said to be successful because of the community's passionate attitude in communicating and implementing development that is by counseling and potential development, which in Kiaralawang village its potential is water hyacinth being used as a creative craft (Interview with AT, village apparatus in Kiaralawang, August 5, 2017). Without excellent communication from Creavill officials, rural development programs, especially food security, could not work. Social communication is the determinant of food security programs succeed and produces progress in the social field that the results of the community more productive and more participative society.

Social communication has also brought rural communities to economic independence. With initial surveys and assessment, Creavill has been able to bring out the economic potential underlying the food security of the community, namely the creation of products from the possibility of Kiaralawang village, which is food and creative craft of water hyacinth. Here also the Creavill party, with its social communication, has succeeded in encouraging people's motivation to cultivate awareness of the potential of this village, Kiaralawang. It follows the development objective of improving the empowerment of rural communities by developing the potential to generate local economy and then improving the quality of human resources in rural areas and conservation protection of natural resources conservation of environmental functions, in this case, Bagendit Situ conservation.

The success of this empowerment program is inseparable from the success indicators held by Creavill. The indicators are:

1. The existence of community participation. 
2. The potential and problems of locally empowered, as well as water hyacinth, come from local problems in Kampung Kiaralawang.

3. The participation of business groups and craft groups.

4. The existence of products that can be marketed,

5. The presence of local cadres (Interview with KA, community leader Kiaralawang, August 5, 2017).

This indicator of success is evidenced by the Creavill empowerment program implemented in the village of Kiaralawang that the community of Kiaralawang village has a high participation is seen with Creavill solve the problem that is water hyacinth covering Bagendit then from this problem is made potency water hyacinth that can be made food and craft, then together planning, executing production by the creative hyacinth creative group, and evaluating it. All these processes are inseparable from social communication efforts by Creavill activists (Interview with IM, artisans at Kiaralawang, August 5, 2017).

So the results of empowerment is the creation of water hyacinth crafts that are of economic value and then also supported by the youth who play an active role in developing and assisting the creative craft community of water hyacinth, so that these young people are called as local cadres, which this local cadre served as a liaison between creative craft group and Creavill by giving information about the development of creative craft of water hyacinth then if there is event in Garut about SMEs Creavill always give information to mothers hence this creation of society of kampung Kiaralawang independently sustainability through food security program. 
It is under the concept of sustainability which is the development of partnership, in this case, Creavill with all levels of the community of Kiaralawang village through excellent social communication, so that sustainable development program through empowerment can be accepted socially and economically by the people of Kiaralawang village and bring the community to self-sufficiency in food and economy.

\section{E. CONCLUSION}

The development of food security can be done through social communication. In agricultural villages like Kiaralawang, this social communication can be built through the Creavill Community Program (Creative Village). The program has encouraged the emergence of food-making activities and water hyacinth crafts by the mothers of Kiaralawang, Rumba (Rumah Baca; Reading House), Creative Class, and sheep farming. To maintain the quality of the program, all its implementation uses a series of activities such as initial surveys, assessment using PRA (Participatory Rural Appraisal) methods, program implementation, monitoring, and evaluation.

Support gained by Creavill Community in village community empowerment in Kampung Kiaralawang is a useful community response, a high level of community participation, and availability of natural resources in Kampung Kiaralawang. Then the obstacle factor is the lack of synergy with the government, also the ignorant of hyacinth artisans in marketing their products.

The impact of Creavill community empowerment to the community of Kiaralawang village is the marketable product that is food and water hyacinth 
handicraft, the more productive and creative society; the children are motivated to be more enthusiastic in learning because it is facilitated by Rumba (Rumah Baca) and creative class. Economic activity with the production of water hyacinth has made the community Kiaralawang, Banyuresmi, Garut is self-sufficient and can be empowered in food both in production, distribution, and consumption.

\section{REFERENCES}

Anwar, R. K., Rusmana, A., \& Rahman, M. T. (2018). The Politics Of Information On Traditional Medical Practices In Bandung Barat. MIMBAR. Jurnal Sosial dan Pembangunan, 34(1).

Ascani, Andrea; Riccardo Cresscenzi, Simona Iamarino. (2012). Regional Economic Development: A Review. European Commission. WP1/03. Search Working Paper.

Chistilin D. K. (2006). "Self-organization of the World Economy: Euro-Asian Aspect". -M., Economika.

Creswell, John W. (2010). Research Design: Pendekatan Kualitatif, kuantitatif, dan Mixed. Yogyakarta: Pustaka Pelajar.

Dang, G. \& L. Sui Pheng. (2015). Infrastructure Investments in Developing Economies. Singapore: Springer.

Der Wagen, Lynn. (2001). Event Management: For Tourism, Cultural, Business and Sporting Events. Sydney: Hospitality Press Melbourne.

Lewis, Jeffrey. (1991). Reevaluating the Effect of N-ach on Economic Growth. World Development 19 (9): 1269-1274.

Moleong, Lexy J. (2012). Metodologi Penelitian Kualitatif. Bandung: Remaja Rosdakarya. 
Naude, Wim. (2013). Entrepreneurship and Economic Development: Theory, Evidence, and Policy. Bonn: IZA.

Prihartono, Bambang. (2012). Arah Kebijakan dan Prioritas Pembangunan Transportasi Jangka Panjang. Jakarta: Bappenas.

Rakhmat, Jalaluddin. (2012). Metode Penelitian Komunikasi: Dilengkapi Dengan Contoh Analistik Statistik. Bandung: Rosdakarya.

Santos, M. E., Dabus, C., and Delbianco, F. (2016). "Growth and poverty revisited from a multidimensional perspective.” OPHI Working Paper 105, University of Oxford.

Supratman, Lucy Pujasari. (2017). Communicative Leadership in Constructing Innovative Learning Organization. Mimbar, Vol. 33 No. 2, December 2017. 